\title{
ANALISIS KINERJA BERDASARKAN LAPORAN KEUANGAN PADA PT. BANK SUL-SELBAR CABANG PALOPO
}

\author{
Muh. Halim ${ }^{1}$, Haedar ${ }^{2}$, Ayu Safitry Kira ${ }^{3}$ \\ 1) Dosen Sekolah Tinggi Ilmu Ekonomi Muhammadiyah Palopo \\ ${ }^{2,3)}$ Dosen Sekolah Tinggi Ilmu Ekonomi Muhammadiyah Palopo
}

\begin{abstract}
Abstrak: Bank kegiatan utamanya adalah penghimpunan dana dari masyarakat kemudian menyalurkannya dengan tujuan untuk memper oleh laba, Oleh karenanya penting bagi bank untuk menjaga kepercayaan masyarakat

Penelitian ini bertujuan untuk mengetahui kinerja keuangan pada PT.Bank Sul-Selbar Cabang Palopo. Jenis dan sumber datanya adalah data sekunder dalam bentuk kuantitatif yakni dalam bentuk laporan keuangan (laporan neraca dan laba rugi). Tehnik pengumpulan datanya adalah dengan penelitian lapangan dan kepustakaan. Data ini diolah dengan rasio keuangan yakni rasio likuiditas, rasio solvabilitas, dan rasio rentabilitas, untuk mengetahui kinerja dan kondisi keuangan pada PT.Bank Sul-Selbar Cabang Palopo. Hasil penelitian ini menunjukan rentabilitas perusahaan selama tahun 2011 - 2014 mengalami peningkatan dari tahun ketahun.
\end{abstract}

Kata kunci: Kinerja keuangan, Laporan keuangan, Rasio likuiditas, Rasio solvabilitas, Rasio rentabilitas.

\section{PENDAHULUAN}

Untuk mengukur posisi keuangan dan kinerja suatu bank dapat dilakukan dengan menganalisis suatu laporan keuangan. Dan untuk menganalisisnya dapat digunakan dengan analisis rasio-rasio keuangan yaitu, rasio likuiditas (liquidity ratio), rasio solvabilitas (solvency ratio), rasio rentabilitas . Tujuan yang ingin dicapai dengan dilakukannya penelitian ini adalah untuk mengetahui kinerja dan kondisi keuangan PT. Bank Sul-Selbar Cabang Palopo dengan menganalisis rasio keuangannya dari laporan keuangannya selama 4 (empat) periode 2011, 2012, 2013, dan 2014.

Analisis rasio keuangan sangatlah erat kaitannya dengan laporan keuangan karena dengan laporan keuangan, suatu analisis dapat dilakukan. Laporan keuangan dapat disusun dan disajikan dengan maksud untuk memberikan informasi kuantitatif mengenai keadaan keuangan pada periode tertentu.
Kesehatan suatu bank merupakan kepentingan semua pihak, baik pemilik dan pengelola bank, masyarakat pengguna jasa bank, maupun bank Indonesia selaku pembina dan pengawas bank. Dengan pesatnya perkembangan yang terjadi di bidang keuangan dan perbankan maka telah terjadi perubahan yang cukup berpengaruh terhadap berbagai aspek yang berkaitan dengan kesehatan bank.

Tingkat kesehatan bank dapat dilihat dari berbagai indikator. Salah satu sumber utama indikator yang dijadikan dasar penilaian adalah laporan keuangan bank yang bersangkutan. Berdasarkan laporan itu akan dapat dihitung sejumlah rasio yang lazim dijadikan tingkat dasar penilaian tingkat kesehatan bank.

Pada umumnya suatu perusahaan didirikan dengan tujuan untuk memperoleh laba. Laba merupakan hasil yang menguntungkan atas usaha yang dilakukan oleh perusahaan pada suatu periode tertentu. Dengan laba, perusahaan dapat 
menggunakannya sebagai tambahan untuk pembiayaan dalam menjalankan usahanya.

Namun demikian, tidak selamanya laba dapat diandalkan oleh perusahaan sebagai tambahan untuk pembiayaan dalam menjalankan usahanya. Hal ini disebabkan oleh karena kondisi tertentu yang dialami perusahaan, seperti perusahaan sedang mengalami kerugian atau tingkat penjualan perusahaan tidak mencapai target. Kondisi ini kemudian mengakibatkan modal perusahaan menjadi berkurang, dan laba yang diperoleh tidak mencukupi sehingga keduanya tidak akan dapat diputarkan kembali menjadi persediaan barang dagangan.

Untuk mengetahui kondisi perusahaan, dapat dilakukan pemeriksaan salah satunya adalah penilaian terhadap kinerja perusahaan. Kinerja perusahaan mencerminkan seberapa jauh tingkat kesehatan dan kemajuan yang dimiliki/dicapai oleh perusahaan.

Ada dua aspek dalam melakukan penilaian terhadap kinerja perusahaan. Aspek pertama adalah keuangan dan aspek kedua anggapan bahwa selain kondisi/keadaan keuangan perusahaan dapat mencerminkan keadaan perusahaan yang sebenarnya. Kondisi keuangan perusahaan juga menunjukkan apakah usaha yang dijalani oleh perusahaan tersebut profitable atau tidak. Inilah yang menjadi nilai lebih/tambah pada aspek keuangan dari pada aspek non keuangan. Pada aspek non keuangan, hal semacam ini tidak akan terlihat. Aspek non keuangan hanya mencerminkan kinerja perusahaan yang lebih mengarah kepada hal kemanajerialan atau keorganisasian perusahaan.

Penilaian kinerja pada aspek keuangan perusahaan lebih sering menggunakan teknik analisis rasio keuangan. Analisis rasio keuangan membutuhkan laporan keuangan selama sedikitnya 2 (dua) tahun terakhir dari berjalannya perusahaan.

Dengan analisis rasio keuangan, akan dapat diketahui berapa tingkat likuiditas, solvabilitas dan rentabilitas yang dimiliki oleh perusahaan.

Tingkat likuiditas adalah menunjukkan sejauh mana kemampuan perusahaan dalam memenuhi kewajiban jangka pendeknya dengan jaminan harta lancar yang dimilikinya. Tingkat likuiditas ini berguna bagi kreditur yang akan memberikan kredit jangka pendek.

Sedangkan tingkat solvabilitas, menunjukkan sejauh mana kemampuan perusahaan dapat memenuhi semua kewajibannya dengan jaminan harta yang dimilikinya. Tingkat solvabilitas ini berguna bagi kreditur yang akan memberikan kredit jangka pendek maupun jangka panjang.

Terakhir adalah tingkat rentabilitas, menunjukkan sejauh mana kemampuan perusahaan dalam menghasilkan laba dengan modal yang dimilikinya. Hal ini sangat penting untuk mengetahui efisiensi dari suatu perusahaan.

Dengan mengetahui tingkat likuiditas, solvabilitas, dan rentabilitas suatu perusahaan, akan dapat diketahui keadaan perusahaan yang sesungguhnya sehingga lembaga atau individu selaku kreditur dapat mempunyai keputusan yang mendukung dalam menentukan layak atau 
tidaknya suatu pembiayaan akan diberikan olehnya.

\section{BAHAN DAN METODE}

sumber data yang penulis gunakan yaitu data sekunder dalam bentuk kuantitatif, yakni laporan keuangan dalam bentuk neraca dan laporan rugi/laba yang diperoleh dari PT. Bank Sul-Sel Cabang Palopo. Populasi dalam penelitian ini adalah laporan keuangan selama tahun berdirinya sampai sekarang (2015) kantor PT.Bank Sul-selbar Cabang Palopo. kemudian besarnya sampel tersebut bisa dilakukan dengan menggunakan data laporan keuangan selama 4 tahun mulai 2011 sampai 2014. Setelah data dikumpulkan lalu diolah untuk mengetahui kinerja perusahaan menggunakan analisis rasio keuangan.

\section{HASIL DAN PEMBAHASAN}

\section{Rasio likuiditas (current ratio)}

\begin{tabular}{|c|c|c|c|}
\hline Tahun & $\begin{array}{c}\text { Current } \\
\text { ratio } \\
(\%)\end{array}$ & $\begin{array}{c}\text { Pertumbuhan } \\
(\%)\end{array}$ & $\begin{array}{c}\text { Perkembangan } \\
(\%)\end{array}$ \\
\hline 2011 & 200,67 & - & - \\
\hline 2012 & 278,78 & 78,11 & 38,92 \\
\hline 2013 & 281,32 & 2,54 & 0,90 \\
\hline 2014 & 226,64 & $-54,68$ & $-19,43$ \\
\hline
\end{tabular}

Berdasarkan tabel di atas maka dapat diketahui bahwa pertumbuhan rasio likuiditas berfluktuasi (naik turun), yaitu pada tahin 2012 mengalami peningatan sebesar Rp 78,11 dan pada tahun 2013 mengalami peningkatan sebesar Rp 2,54, sedangkan pada tahun 2014 mengalami penurunan sebesr $\mathrm{Rp}-54,68$. Namun current ratio berada pada tingkat yang sangat likuid. Perkembangan pada tahun 2012 meningkat sebesar Rp 38,92, sedangkan pada tahun 2013 perkembangannya menjadi Rp 0,91, sedangkan pada tahun 2014 mengalami penurunan sebesar Rp $-19,43$.

$$
\text { Quick Ratio }=\frac{\text { Aset Lancar - Persediaan }}{\text { Utang Lancar }} \times 100 \%
$$

Quick ratio memberikan indikator yang lebih baik dalam melihat likuiditas perusahaan dibandingkan dengan current ratio.

$$
\text { 231.727.421.929,93 - 40.540.669,30 }
$$

Thn $2011=$ X $100 \%$

$$
\text { 115.474.661.138,03 }
$$

$$
=\operatorname{Rp} 200,63 .
$$

Hasil perhitungan Quick Ratio, pada tahun 2011 menunjukkan angka rasio sebesar Rp 200,63 hal ini berarti bahwa setiap Rp.100 utang lancar dijamin dengan aktiva lancar yang mudah diuangkan sebesar Rp 200,63.

$313.006 .264 .107,18-54.762 .153,89$

Thn $2012=$ x $100 \%$

$$
\text { 112.277.788.741,17 }
$$

$$
=\operatorname{Rp} 278,73
$$

Hasil perhitungan Quick Ratio, pada tahun 2012 menunjukkan angka rasio sebesar Rp 278,73 hal ini berarti bahwa setiap Rp.100 utang lancar 
dijamin dengan aktiva lancar yang mudah diuangkan sebesar Rp 278,73.

$346.211 .716 .057,16-58.732 .930,00$

Thn $2013=$ $100 \%$

$129.465 .387 .929,07$

$=\operatorname{Rp} 267,37$.

Hasil perhitungan Quick Ratio, pada tahun 2013 menunjukkan angka rasio sebesar Rp 267,37 hal ini berarti bahwa setiap Rp.100 utang lancar dijamin dengan aktiva lancar yang mudah diuangkan sebesar Rp 267,37.

$$
\text { 394.416.782.006,67 - 78.033.836,00 }
$$

Thn $2014=$

$174.027 .424 .669,86$

$=\operatorname{Rp} 226,59$.

Hasil perhitungan Quick Ratio, pada tahun 2014 menunjukkan angka rasio sebesar Rp 226,59 hal ini berarti bahwa setiap Rp.100 utang lancar dijamin dengan aktiva lancar yang mudah diuangkan sebesar Rp 226,59.

Rumus menghitung :

Perkembangan $=\mathrm{t}_{1-} \mathrm{t}_{0}$

$$
\text { Perkembangam }=\frac{\mathrm{t}_{1-} \mathrm{t}_{0}}{\mathrm{t}_{0}} \times 100 \%
$$

\section{Rasio likuiditas (Quick Ratio)}

\begin{tabular}{|c|c|c|c|}
\hline Tahun & $\begin{array}{c}\text { Quick } \\
\text { ratio } \\
(\%)\end{array}$ & $\begin{array}{c}\text { Pertumbuhan } \\
(\%)\end{array}$ & $\begin{array}{c}\text { Perkembangan } \\
(\%)\end{array}$ \\
\hline 2011 & 200,63 & - & - \\
\hline 2012 & 278,73 & 78,10 & 38,92 \\
\hline 2013 & 267,37 & $-11,36$ & $-0,07$ \\
\hline 2014 & & $-40,78$ & $-15,25$ \\
\hline
\end{tabular}

Dari tabel di atas dapat diketahui bahwa pertumbuhan pada tahun 2011 belum dapat dietahui karena merupakan tahun dasar. Pada tahun 2012 pertumbuhan Quick ratio sebesar Rp 78,10, dan pada tahun 2013 dan 2014 mengalami penurunan. Pada tahun 2012 perkembangan quick ratio yaitu sebesar $\mathrm{Rp} \mathrm{38,92,} \mathrm{dan} \mathrm{pada} \mathrm{tahun} 2013$ mengalami penurunan sebesar Rp 0,07, sedangkan pada tahun 2014 mengalami penurunan sebesar Rp $-15,25$.

$$
\text { Aset Lancar - Utang Lancar }
$$

Net Working

Capital $(N W C)=$

Total Aktiva

Rasio ini digunakan untuk mengetahui rasio modal bersih terhadap utang lancar.

231.727.421.929,93 - 115.474.661.138,03

$N W C 2011=$ $100 \%$

238.587.950.510,23

$$
=\operatorname{Rp} 48,72 \text {. }
$$

Jika rata-rata Inventory to Net Working Capital adalah Rp 40, maka keadaan usaha pada 
tahun 2011 baik karena di atas rata-rata yaitu Rp 48,72 .

313.006.264.107,18 - 112.277.788.741,17 NWC $2012=$

319.901.014.172,07

$=\operatorname{Rp} 97,46$.

Jika rata-rata Inventory to Net Working Capital adalah $\mathrm{Rp}$ 40, maka keadaan usaha pada tahun 2012 baik karena di atas rata-rata yaitu $\mathrm{Rp}$ 97,46 .

364.211.716.057,16 - 129.465.387.927,07 NWC $2013=$ $366.677 .679 .790,16$

$=\operatorname{Rp} 64,02$.

Jika rata-rata Inventory to Net Working Capital adalah Rp 40, maka keadaan usaha pada tahun 2013 baik karena di atas rata-rata yaitu Rp 64,02 .

394.416.782.006,67 - 174.027.424.669,86 NWC $2014=$ $\mathrm{x} 100 \%$ 401.323.653.753,67

$=\operatorname{Rp} 54,91$.

Jika rata-rata Inventory to Net Working Capital adalah $\mathrm{Rp}$ 40, maka keadaan usaha pada tahun 2014 baik karena di atas rata-rata yaitu Rp 54,91
Rumus menghitung :

Pertumbuhan $=\mathrm{t}_{1-} \mathrm{t}_{0}$
$\mathrm{t}_{1-} \mathrm{t}_{0}$
Perkembangan $=\stackrel{\text { - }}{=} 100 \%$

$\mathrm{t}_{0}$

\section{Rasio likuiditas (Net working capital)}

\begin{tabular}{|c|c|c|c|}
\hline Tahun & $\begin{array}{c}\text { NWC } \\
(\%)\end{array}$ & $\begin{array}{c}\text { Pertumbuhan } \\
(\%)\end{array}$ & $\begin{array}{c}\text { Perkembangan } \\
(\%)\end{array}$ \\
\hline 2011 & 48,72 & - & - \\
\hline 2012 & 97,46 & 48.74 & 100.04 \\
\hline 2013 & 64,02 & $-33,44$ & $-34,31$ \\
\hline 2014 & 54,91 & $-9,11$ & $-14,23$ \\
\hline
\end{tabular}

Dari tabel di atas dapat diketahui bahwa pertumbuhan Net Working Capital pada tahun 2011 belum dapat diketahui karena merupakan tahun dasar. Pada tahun 2012 pertumbuhan net working capital sebesar Rp 48,74, pada tahun 2013 pertumbuhan net working capital menurun sebesar Rp -33,44, dan pertumbuhan pada tahun 2014 juga menurun sebesar Rp -9,11. Sedangkan perskembangan net working capital pada tahun 2012 yaitu sebesar Rp 100,04 sedangkan pada tahun 2013 mengalami penurunan sebesar Rp 34,31 dan 2014 mengalami penurunan sebesar Rp $-14,23$.

\section{Rasio solvabilitas}

Rasio solvabilitas adalah perhitungan yang bertujuan untuk menunjukkan sejauh mana perusahaan dibiayai oleh utang (dana pihak luar) rasio ini juga menunjukkan indikasi tingkat keamanan dari para pemberi pinjaman dalam hal ini adalah pihak bank yang diwakili. 
Total Utang

Rasio Total Utang terhadap $=\longrightarrow \times 100 \%$

Total Harta

Total Harta

$119.628 .660 .075,37$

Thn $2011=\longrightarrow \times 100 \%$

238.587.950.510,23

$=\operatorname{Rp} 50,14$.

Hasil perhitungan pada tahun 2011 menunjukkan rasio sebesar Rp 50,14 hal ini berarti bahwa setiap Rp.100 totAlmghatudigmin dengan total utang sebesar Rp 50,14.

129.989.746.026,17

Thn $2012=\longrightarrow \times 100 \%$

319.901.074.172,07

$=\operatorname{Rp} 40,63$.

Hasil perhitungan pada tahun 2011 menunjukkan rasio sebesar $\mathrm{Rp}$ 40,63 hal ini berarti bahwa setiap Rp.100 total harta dijamin dengan total utang sebesar Rp 40,63.

131.820 .552 .379 .07

Thn $2013=$

$$
\begin{aligned}
& 366.671 .679 .790,16 \\
= & \operatorname{Rp} 35,95 .
\end{aligned}
$$

Hasil perhitungan pada tahun 2011 menunjukkan rasio sebesar $\mathrm{Rp} 35,95$ hal ini berarti bahwa setiap Rp.100 total harta dijamin dengan total utang sebesar Rp 35,95.

174.248.300.747,18

Thn 2014

401.323.653.753,67

$$
=\operatorname{Rp} 43,41 \text {. }
$$

Hasil perhitungan pada tahun 2011 menunjukkan rasio sebesar Rp 43,41 hal ini berarti bahwa setiap Rp.100 total harta dijamin dengan total utang sebesar Rp 43.41.

Pertumbuhan $=\mathrm{t}_{1-} \mathrm{t}_{0}$

$$
t_{1-} t_{0}
$$

Perkembangan $=\longrightarrow 100 \%$

$\mathrm{t}_{0}$

\section{Rasio solvabilitas}

\begin{tabular}{|c|c|c|c|}
\hline Tahun & $\begin{array}{c}\text { Total utang } \\
\text { terhadap total } \\
\text { harta }\end{array}$ & $\begin{array}{c}\text { Pertumbuhan } \\
(\%)\end{array}$ & $\begin{array}{c}\text { Perkembangan } \\
(\%)\end{array}$ \\
\hline 2011 & 50,14 & - & - \\
\hline 2012 & 40,63 & $-9,51$ & $-18,96$ \\
\hline 2013 & 35,95 & 8,85 & 2,18 \\
\hline 2014 & 43,21 & 7,26 & 20,19 \\
\hline
\end{tabular}

Dari table di atas. dapat diketahui bahwa pertumbuhan pada tahun 2011 belum dapat dietahui karena merupakan tahun dasar. Pada tahun 2012 pertumbuhan sebesar $\mathrm{Rp}-9,51$, dan pada tahun 2013 dan 2014 mengalami peningkatan. Pada tahun 2012 perkembangan sebesar Rp -18,96, dan pada tahun 2013 mengalami perkembangan sebesar Rp 2,18, 
sedangkan pada tahun 2014 mengalami penurunan sebesar Rp -20,19.

\section{Rasio Rentabilitas}

$$
\text { Return On Assets }=\frac{\text { Laba Bersih }}{\text { Total Asset }} \times 100 \%
$$

Rasio ini untuk mengetahui kemampuan manajemen bank dalam mengelola aktiva yang digunakan untuk menghasilkan laba. Semakin tinggi rasio menunjukkan hasil yang semakin baik.

69.401.954.729.32

$$
\begin{aligned}
\text { ROA } 2012 & =\frac{\times 100 \%}{319.901 .014 .172,07} \\
& =\operatorname{Rp} 21,69 .
\end{aligned}
$$

Hasil perhitungan Return On Asset, pada tahun 2012 menunjukkan hasil bahwa setiap total asset $\mathrm{Rp} 100$ mampu mehasilkan laba bersih Rp 21,69. Semakin tinggi rasio ini semakin baik.

82.627.141.085,65

$$
\begin{aligned}
\text { ROA } 2013 & =\frac{\times 100 \%}{366.671 .679 .790,16} \\
& =\operatorname{Rp} 22,53 .
\end{aligned}
$$

Hasil perhitungan Return On Asset, pada tahun 2013 menunjukkan hasil bahwa setiap total asset $\mathrm{Rp} 100$ mampu menghasilkan laba bersih $\mathrm{Rp}$ 22,53. Semakin tinggi rasio ini semakin baik.
$99.553 .302 .542,49$

ROA $2014=\longrightarrow \times 100 \%$

401.323.653.753,67

$$
=\operatorname{Rp} 24,80 \text {. }
$$

Hasil perhitungan Return On Asset, pada tahun 2014 menunjukkan hasil bahwa setiap total asset $\mathrm{Rp} 100$ mampu menghasilkan laba bersih $\mathrm{Rp}$ 24,80 semakin tinggi rasio ini semakin baik.

Menghitung:

Pertumbuhan $=\mathrm{t}_{1-} \mathrm{t}$

Perkembangan $=\stackrel{\mathrm{t}_{1-} \mathrm{t}_{0}}{\longrightarrow} \times 100 \%$

$\mathrm{t}_{0}$

\section{Rasio Rentabilitas (ROA)}

\begin{tabular}{|c|c|c|c|}
\hline Tahun & $\begin{array}{c}\text { ROA } \\
(\%)\end{array}$ & $\begin{array}{c}\text { Pertumbuhan } \\
(\%)\end{array}$ & $\begin{array}{c}\text { Perkembangan } \\
(\%)\end{array}$ \\
\hline 2012 & 21,69 & - & - \\
\hline 2013 & 22,53 & 0,84 & 3,87 \\
\hline 2014 & 24,80 & 2,27 & 10,07 \\
\hline
\end{tabular}

Dari tabel di atas dapat diketahui bahwa, pada tahun 2012 pertumbuhan ROA belum dapat diketahui karena merupakan tahun dasar. Pada tahun 2013 pertumbuhan ROA sebesar Rp 0,84, dan pada tahun 2014 mengalami penigkatan sebesar $\mathrm{Rp} 2,27$. yang berarti rasio $R O A$ sangat baik. Dan perkembangan ROA pada tahun 2013 ke 2014 mengalami peningkatan.

\section{Labah Bersih}

Return On Equity = $\longrightarrow-100 \%$

Modal Sendiri 
$=\operatorname{Rp} 43,84$.

Return On Equity (ROE) merupakan indikator yang tepat untuk mengukur keberhasilan bisnis dalam memperkaya pemegang saham. Semakin tinggi rasio ini akan semakin baik karena memberikan tingkat pegembalian yang lebih besar kepada pemegang saham

\subsubsection{M29ghitung:}

$\begin{aligned} \text { ROE } 2012 & =\frac{193.911 .328 .145,90}{} \times 100 \% \\ & =\operatorname{Rp} 35,79 .\end{aligned}$

Hasil perhitungan Return On Equity (ROE) pada tahun 2012 menunjukkan hasil bahwa setiap total modal Rp 100 mampu menghasilkan laba bersih $\mathrm{Rp}$ 35,79. Semakin tinggi rasio ini semakin baik.

$$
\text { 82.627.141.085,6 }
$$

$$
\begin{aligned}
\text { ROE } 2013 & =\frac{234.851 .127 .411,09}{} \times 100 \% \\
& =\operatorname{Rp~35,18.}
\end{aligned}
$$

Hasil perhitungan Return On Equity (ROE) pada tahun 2013 menunjukkan hasil bahwa setiap total modal $\mathrm{Rp} 100$ mampu menghasilkan laba bersih $\mathrm{Rp} 35,18$. Semakin tinggi rasio ini semakin baik.

99.553.302.542.,49

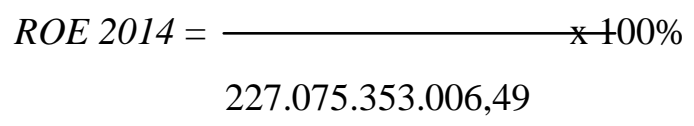

Hasil perhitungan Return On Equity (ROE) pada tahun 2014 menunjukkan hasil bahwa setiap total modal Rp 100 mampu menghasilkan laba bersih $\mathrm{Rp} 43,84$.. Semakin tinggi rasio ini semakin baik.

$$
\begin{gathered}
\text { Pertumbuhan }=\mathrm{t}_{1-} \mathrm{t} \\
\text { Perkembangan }=\frac{\mathrm{t}_{1-} \mathrm{t}_{0}}{\mathrm{t}_{0}} \times 100 \%
\end{gathered}
$$

\section{Rasio Rentabilitas (ROE)}

\begin{tabular}{|c|c|c|c|}
\hline Tahun & $\begin{array}{c}\text { ROE } \\
(\%)\end{array}$ & $\begin{array}{c}\text { Pertumbuhan } \\
(\%)\end{array}$ & $\begin{array}{c}\text { Perkembangan } \\
(\%)\end{array}$ \\
\hline 2012 & 35,79 & - & - \\
\hline 2013 & 35,18 & $-0,61$ & $-1,70$ \\
\hline 2014 & 43,84 & 8,66 & 24,61 \\
\hline
\end{tabular}

Dari tabel di atas dapat diketahui bahwa, pada tahun 2012 pertumbuhan $R O E$ belum dapat diketahui karena merupakan tahun dasar. Pada tahun 2013 pertumbuhan ROE sebesar Rp -0,61, dan pada tahun 2014 mengalami penigkatan sebesar Rp 8,66 yang berarti rasio ROE sangat baik. Dan perkembangan ROE pada tahun 2013 ke 2014 mengalami peningkatan.

\section{SIMPULAN}

1) Kinerja PT.Bank Sul-Sel Cabang Palopo dapat diukur dengan menerapkan analisis rasio keuangan yakni rasio likuiditas, solvabilitas serta rentabilitas. PT.Bank Sul-Selbar Cabang Palopo dalam mengelola keuangan yaitu periode 2011- 
2014 semakin efisien dari tahun ke tahun. 2) Pada analisis rasio rentabilitas PT. Bank Sul-Sel Cabang Palopo, menunjukkan kemampuan keuangan perusahaan untuk menghasilkan laba.

\section{DAFTAR PUSTAKA}

Ahmadi, Abu dan Cholid Narbuko, 1997, Metodologi Penelitian Jakarta.

Agnes Sawir, 2009, Analisa Kinerja Keuangan dan Perencanaan Keungan Perusahaan, Jakarta, Gramedia Pustaka Utama.

Astuti, 2004, Manajemen Keuangan Perusahaan, Penerbit Ghalia Indonesia, Jakarta.

Abdullah, 2001, Dasar-Dasar Manajemen Keuangan, Penerbit Universitas Muhammadiyah Malang, Malang.

Donald D.E.Kieso, Jerry J Weygandt, Terry D Warfieid, 1999, Akuntansi Intermediate, edisi kesepuluh, jlid pertama.

Erich A. Helfert, D.B.A, 2003, Analisis Laporan Keuangan, Edisi Ketujuh, Penerbit Erlangga. Jakarta.

Eugene F. Brigham, Joel F. Houston, 2006, DasarDasar Manajemen Keuangan, Buku 1, Edisi 10, Penerbit Salemba Empat, Jakarta.

Ilyas, 2001, Penilaian dan Penelitian Kinerja, Jakarta.

Martono, 2005, Manajemen Keuangan, Penerbit' Ekonisia. Jakarta

Syamsuddin, 2009, Manajemen Keuangan Perusahaan, Penerbit. PT. Raja Grafindo Persada, Jakarta.

Sugiyono, 2011, Metode Penelitian Kuantitatif, Kualitatif \& $\mathbf{R}$ dan D, Bandung : Alfabeta.
Sholihin, 2004/2005 Akuntan, M,Acc, Akuntasi Manajemen, Fak. Ekonomi UGM, Yogyakarta.

Soemarso, 2004, Akuntansi Suatu Pengantar, Salemba Empat, Jakarta.

Warsono, 2003, Manajemen Keuangan Perusahaan, Edisi 3, Jilid 1, Penerbit Bayumedia Publishing. Jakarta. 